\title{
PENENTUAN GOLONGAN SEYAWA DAN TOTAL FLAVONOID EKSTRAK ETANOL SARANG SEMUT (Myrmecodia pendens Merr \& Perry) SECARA SPEKTROFOTOMETRI UV-VIS
}

\section{DETERMINATION OF COMPOUNDS TYPES AND FLAVONOIDS TOTAL FROM Myrmecodia pendens Merr \& Perry ETHANOL EXTRACT BY UV-VIS SPECTROPHOTOMETRY}

\author{
1)Susilowati, 2)Dian Estiningrum \\ 1abisalumisri@gmail.com dan 2dian.esty@yahoo.com \\ 1,2DIII Farmasi STIKES Nasional, Surakarta
}

Intisari

Sarang semut merupakan tanaman yang telah banyak digunakan sebagai pengobatan tradisional. Salah satu kandungan kimia dalam sarang semut yang bertanggungjawab terhadap potensinya adalah flavonoid. Tujuan dari penelitian ini adalah untuk mengetahui golongan dan kadar flavonoid total pada sarang semut. Metode ekstraksi menggunakan maserasi dengan pelarut etanol $96 \%$. Uji kualitatif dilakukan dengan skrining fitokimia dan KLT yang menggunakan fase diam silika GF $_{254}$ $\mathrm{nm}$ dan fase gerak butanol : asam asetat : air (4:1:5). Penentuan golongan flavonoid dan uji kuantitatif dilakukan menggunakan metode spektrofotometri UV-Vis. Hasil penelitian menunjukkan bahwa di dalam ekstrak sarang semut mengandung flavonoid jenis Flavonol yang mengandung $3-\mathrm{OH}$ bebas dan mempunyai $5-\mathrm{OH}$ bebas. Kadar flavonoid total terhadap kuercetin pada ekstrak etanol sarang semut sebesar 0,6126 $\% \mathrm{~b} / \mathrm{b}$.

Kata kunci : Sarang semut, golongan flavonoid, KLT, spektrofotometri

\begin{abstract}
Myrmecodia pendens Merr.\& Perry. is a plant that has been widely used as a traditional medicine. One of the chemical active componen in Myrmecodia pendens is flavonoid. The purpose of this study was to determine flavonoid group and that content in Myrmecodia pendens. Extraction method used maceration with 96\% ethanol. Qualitative test conducted by phytochemical screening and TLC with stationary phase silica GF254nm and buthanol:acetic acid: water ( 4:1:5) as mobile phase. Flavonoid group dan quanitative assay used UV-Vis spectrophotometry methode. The results showed that in Myrmecodia pendens extract contains flavonoids kind Flavonols 3-OH-free and 5-OH-free. Flavonoid total of Myrmecodia pendens ethanol extract $0,6126 \% \mathrm{~b} / \mathrm{b}$ of quercetine.
\end{abstract}

Keywords: Myrmecodia pendens, flavonoids , TLC, spectrophotometry

\section{Pendahuluan}

Salah satu tanaman obat Indonesia adalah sarang semut (Myrmecodia pendens). Sarang semut merupakan tanaman obat asal Papua yang memiliki kandungan flavonoid, tanin, dan polifenol yang berfungsi sebagai antioksidan (Subroto dan Saputro, 2006). Selain sebagai antioksidan senyawa aktif polifenol yang terkandung dalam sarang semut memiliki banyak khasiat diantaranya sebagai antimikroba, antidiabetes, dan antikanker (Frengki, dkk. 2014).

Penelitian terkait Sarang semut sudah banyak dilakukan di Indonesia. Efek sitotoksik ekstrak etanol sarang semut (Myrmecodia pendens) pada sel Kanker Serviks HeLa cukup aktif dengan nilai $\mathrm{IC}_{50}$ sebesar $33,28 \mu \mathrm{g} / \mathrm{ml}$ (Fatmawati, dkk 2011). Pada pengujian aktivitas antioksidan Sarang Semut (Myrmecodia pendans), fraksi air menunjukkan nilai $\mathrm{IC}_{50}$ lebih besar, yaitu 37,25 ppm dibandingkan dengan fraksi butanol, 
yaitu 49,69 ppm (Suharyanto,dkk., 2012). Penelitian oleh Marianti (2012) menunjukkan bahwa fraksi nheksana : etil asetat $(10: 90)$ memiliki aktivitas antibakteri aktif terhadap Escherichia coli dengan nilai Konsentrasi Bunuh Minimum (KBM) 0,062\% (b/v), sedangkan pada fraksi etil asetat : metanol (90:10) memiliki aktivitas antibakteri aktif terhadap Bacillus cereus dengan nilai $\mathrm{KBM} 0,437 \%(\mathrm{~b} / \mathrm{v})$. Berdasarkan hal tersebut menunjukkan Sarang semut berpotensi untuk dikembangkan sebagai obat tradisional.

Flavonoid adalah suatu kelompok senyawa fenol yang terbesar yang ditemukan di alam. Senyawa ini meruapakan zat merah, ungu, biru, dan sebagai zat warna kuning yang ditemukan dalam tumbuhtumbuhan. Aktivitas anti oksidatif flavonoid bersumber pada kemampuan mendonasikan atom hidrogennya atau melalui kemampuannya mengkelat logam. Berbagai hasil penelitian menunjukkan bahwa senyawa flavonoid mempunyai aktivitas antioksidan (Redha,2010). Flavonoid digolongkan berdasarkan penambahan rantai oksigen dan perbedaan distribusi dari gugus hidroksil antara flavonol,isoflavon, flavanon, flavanonol dan khalkon (Marby, et al,1970). Berdasarkan informasi tersebut, perlu dilakukan penentuan golongan flavonoid dan penetapan kadar total flavonoid dalam ekstrak etanol sarang semut sehingga bisa digunakan sebagai bahan aktif obat tradisional dan dapat diginakan sebagai dasar perhitungan dosis dalam pemeriksaan mutu.

\section{Metode Penelitian}

\section{Alat}

Beker gelas PYREX $500 \mathrm{~mL}, 250 \mathrm{~mL}$, $100 \mathrm{~mL}, 50 \mathrm{~mL}, 25 \mathrm{~mL}, 10 \mathrm{~mL}$, Gelas ukur $500 \mathrm{~mL}$, $250 \mathrm{~mL}$, Batang pengaduk, Cawan porselen, Erlenmeyer $250 \mathrm{~mL}, 50 \mathrm{~mL}$, Spektrofotometri Mini Shimadzu, Bejana Penjenuhan, Lampu UV 254,366, Rotary Evaporator, Oven.

\section{Bahan}

Bahan yang digunakan dalam penelitian ini adalah simplisia sarang semut dari supplier papua, aquadest, etanol $96 \%, \mathrm{FeCl} 3$, asam galat, reagen Folin-Ciocalteu, Na2CO3 p.a, rutin p.a, $\mathrm{NaNO} 2$ p.a, $\mathrm{AlCl} 3$ p.a , $\mathrm{NaOH}$ p.a , asam formiat, asam borat, eter (Merck, Jerman), Fase diam : KLT silika gel GF 254 , Fase gerak : n-butanol : asam asetat : air $(4: 1: 5)$ (Merck, Jerman).

\section{Jalannya Penelitian}

\section{Persiapan Bahan Baku}

Sebanyak $300 \mathrm{~g}$ simplisia kering sarang semut dipotong-potong kemudian diserbuk/ dihaluskan dengan menggunakan mortir dan blender, diayak dengan ukuran mesh No. 20, setelah itu serbuk kering disimpan dengan kondisi rapat.

2. Ekstraksi
Sebanyak $100 \mathrm{~g}$ serbuk Sarang semut dimasukkan ke dalam beker gelas, kemudian dimaserasi dengan menggunakan cairan penyari etanol 96\% sebanyak $1000 \mathrm{ml}$. Simplisia direndam dalam cairan penyari selama 3 hari, sambil sesekali diaduk. Filtrat disaring setiap 24 jam. Filtrat yang diperoleh dikumpulkan dan cairan penyari diganti dengan yang baru dengan jumlah yang sama dengan yang sebelumnya. Filtrat yang dihasilkan dijadikan satu dan selanjutnya filtrat dikentalkan dengan Rotary evaporator.

3. Analisis Golongan Flavonoid

a. Uji Pendahuluan

- Larutan ekstrak sebanyak $2 \mathrm{~mL}$ ditambah dengan sedikit serbuk seng atau magnesium dan $2 \mathrm{~mL} \mathrm{HCl}$ $2 \mathrm{~N}$. Senyawa flavanoid akan menimbulkan warna jingga sampai merah (Depkes, 2009).

- Ambil larutan percobaan sebanyak $1 \mathrm{~mL}$, uapkan hingga kering dan sisa dibasahi dengan aseton, tambahkan sedikit serbuk asam borat dan asam oksalat. Panaskan hati-hati di atas penangas air (hindari panas yang berlebihan), tambahkan eter. Amati di bawah sinar UV 366. Terjadi flouresensi kuning (Anonim, 1995).

b. Penentuan golongan menggunakan Kromatografi Lapis Tipis

Disiapkan lempeng KLT silika gel $\mathrm{GF}_{254}$ dengan ukuran 2,5 × $10 \mathrm{~cm}$. Fase gerak yang digunakan adalah campuran larutan n-butanol : asam asetat : air (4:1:5) sebanyak $20 \mathrm{~mL}$. Semua larutan dimasukan dalam corong pisah, dicampur dan dibiarkan semalam kemudian diambil fase atasnya (fase butanol). Dilakukan penjenuhan dalam chamber yang telah dilapisi kertas saring pada dinding bagian dalamnya dan segera ditutup rapat. Sebanyak $10 \mathrm{mg}$ sampel dilarutkan ke dalam $1 \mathrm{ml}$ metanol. Dilakukan penotolan pada lempeng sampai totolan mengering, pengulangan penotolan dilakukan apabila totolan pada lempeng KLT belum terlihat ketika diamati di bawah sinar UV pada panjang gelombang $366 \mathrm{~nm}$. Selanjutnya dilakukan elusi. Hasil elusi dibiarkan kering dan selanjutnya dilakukan analisa data. Identifikasi dilakukan terhadap sampel ekstrak sarang semut dan standart rutin.

4. Analisis Kuantitatif flavonoid total dengan Spektrofotometri UV-vis

a. Pembuatan larutan baku quercetin : Larutan baku induk quercetin $1000 \mathrm{ppm}$

- Timbang seksama $100 \mathrm{mg}$ quercetin standar, masukkan dalam labu ukur $100 \mathrm{ml}$ kemudian encerkan dengan metanol hingga tanda.

- Larutan baku kerja quercetin 50 ppm : Pipet 5,0 $\mathrm{ml}$ larutan baku induk, masukkan dalam labu ukur 100 ml kemudian encerkan dengan akuadest hingga tanda.

b. Penentuan Operating Time (OT) 
Sebanyak $1 \mathrm{ml}$ larutan baku kerja quercetin dimasukkan kedalam labu ukur 10,0 ml tambahkan $0,2 \mathrm{ml} \mathrm{AlCl} 3$ digojog. Tambahkan $0,2 \mathrm{ml}$ potasium asetat $1 \mathrm{M}$ tambahkan akuabidest ad $10 \mathrm{ml}$ digojog. Ukur absorbansinya dengan spektrofotometri visible pada panjang gelombang $415 \mathrm{~nm}$ selama 1 jam (diukur tiap 1 menit).

c. Penentuan panjang gelombang maksimum

Buatlah larutan dengan konsentrasi 5 ppm. Dengan cara, pipet $1,0 \mathrm{ml}$ larutan baku kerja quercetin, masukkan dalam labu ukur $10 \mathrm{ml}$ tambahkan $0,2 \mathrm{ml} \mathrm{AlCl} 3$ kemudian digojog. Tambahkan 0,2 $\mathrm{ml}$ potasium asetat 1Mtambahkan akuabidest ad $10 \mathrm{ml}$ digojog. Diamkan pada suhu kamar selamaOT. Lakukan scanning serapan larutan baku quercetin 5 ppm pada panjang gelombang 400$500 \mathrm{~nm}$. Amati spektrogram berupa kurva hubungan antara panjang gelombang dan absorbansi larutan baku quercetin 5 ppm. Kemudian tentukan $\lambda$ maksimum dari spektrogram yang diperoleh.

d. Pembuatan kurva baku

Buat seri larutan baku 3, 4, 5, 6, dan 7 ppm dari larutan baku kerja quercetin. Dengan cara pipet sebanyak 0,$6 ; 0,8 ; 1.0 ; 1,2 ;$ dan 1,4 dari larutan baku kerja rutin $50 \mathrm{ppm}$, masing -masing dimasukkan kedalam labu ukur 10,0 $\mathrm{ml}$ tambahkan 0,2 $\mathrm{ml} \mathrm{AlCl} 3$ kemudian digojog. Tambahkan $0,2 \mathrm{ml}$ potasium asetat $1 \mathrm{M}$ dan tambahkan akuabidest ad $10 \mathrm{ml}$ digojog. Diamkan pada suhu kamar hingga tercapai OT. Ukur serapan masing -masing seri larutan baku pada $\lambda$ maksimum mulai dari kadar paling kecil. Hitung persamaan regresi linier yang merupakan hubungan antara konsentrasi vs absorbansi, serta tentukan koefisien korelasinya. Buat kurva hubungan konsentrasi vs absorbansi.

e. Penetapan kadar sampel

Pipet $0,5 \mathrm{ml}$ larutan sampel induk $100 \mathrm{mg} \%$ masing -masing dimasukkan ke dalam labu ukur 100 $\mathrm{ml}$, encerkan dengan akuadest hingga tanda. Lakukan pemipetan larutan sampel induk secara triplo. Selanjutnya ukur serapan sampel pada masing masing sampel pada $\lambda$ maksimum. Hitung kadar flavonoid total dalam larutan sampel kerja menggunakan persamaan kurva baku, kemudian hitung flavonoid total dalam sarang semut.

\section{Analisa Data}

1. Identifikasi golongan flavonoid

Hasil deteksi dibawah sinar UV dengan panjang gelombang $366 \mathrm{~nm}$ sebelum diuapi dan setelah diuapi dengan NH3. amati flouresensi yang terjadi. Penentuan golongan flavonoid berdasarkan karakterisasi golongan flavonoid menggunakan spektrofotometri UV-Vis (Markham, 1988). Nilai HRf tiap sampel diperoleh dengan rumus :

$$
\mathrm{HRf}=\frac{\text { jarak titik pusat bercak dari titik awal }}{\text { jarak garis depan dari titik awal }} \times 100
$$

\section{Analisis data kadar flavonoid}

Analisis data kuantitatif dari hasil data spektrofotometri yang menyatakan hubungan antara absorbansi dan konsentrasi akan linier.

Persamaan regresi linier :

$$
\begin{array}{ll} 
& \mathbf{y}=\mathbf{b x}+\mathbf{a} \\
\text { ket. } \quad & \mathrm{y}: \text { absorbansi } \\
& \mathrm{b} ; \text { slope } \\
\mathrm{x}: \text { kadar } \\
\mathrm{a}: \text { intercept }
\end{array}
$$

\section{Hasil dan Pembahasan}

Simplisia serbuk dimaserasi dengan etanol $96 \%$ selama 3 hari sambil sesekali diaduk yang tiap 24 jam disaring. Perendaman selama 3 hari ditujukan menghindari tingkat kejenuhan cairan penyari dan pengadukan bertujuan untuk menjaga perbedaan konsentrasi di dalam dan di luar sel sehingga cairan penyari akan tetap dapat menyari zat sesuai dengan sifat kepolarannya. Filtrat dijadikan satu kemudian filtrat dikentalkan dengan Rotary evaporator. Digunakan rotary evaporator untuk menguapkan kembali pelarut yang digunakan pada saat maserasi sehingga didapat ekstrak kental dari sampel. Proses ekstraksi maserasi merupakan ekstraksi tipe dingin, metode ekstraksi ini dipilih karena sifat flavonoid yang tidak tahan terhadap pemanasan. Untuk pelarut etanol 96\% digunakan karena pelarut ini merupakan pelarut yang universal, etanol 96\% merupakan senyawa polar yang baik dalam mengekstrak senyawa flavonoid yang terkandung dalam suatu bahan. Hasil ekstraksi yang didapat berupa ekstrak kental coklat dengan aroma khas. Rendemen ekstrak etanol yang diperoleh sebesar 12,6996\%.

\section{Analisis Golongan Flavonoid dalam Ekstrak}

1. Pendahuluan

Uji flavonoid dideteksi dengan serbuk seng dan $\mathrm{HCl} 2 \mathrm{~N}$. Senyawa flavonoid akan menimbulkan warna merah jingga sampai merah (Depkes, 2009). Magnesium mudah larut dalam suasana asam dan menghasilkan kation bivalen $\mathrm{Mg}^{2+}$ serta gas hidrogen. Hasil penelitian menunjukkan ekstrak sarang semut positif mengandung flavonoid karena berwarna merah jingga setelah penambahan $\mathrm{Mg}$.

Uji flavonoid kedua dilakukan dengan menguapkan $1 \mathrm{~mL}$ filtrat sampai kering, untuk menghilangkan sisa pelarut yang ada. Kemudian ditambahkan aseton, asam borat dan asam oksalat. Penambahan ini ditujukan untuk memperpanjang pergeseran batokromik sehingga dapat menyerap serapan yang lebih panjang dan mampu berflouresensi pada panjang gelombang $366 \mathrm{~nm}$. Flavonoid yang memiliki gugus hidroksi berkedudukan orto akan memberikan flouresensi 
kuning intensif pada UV $366 \mathrm{~nm}$, jika bereaksi dengan asam borat (Astarina, 2013). Berdasarkan uji flavonoid ekstrak sarang semut, dapat disimpulkan mengandung flavonoid dengan dibuktikan adanya flouresensi kuning.

2. Analisis flavonoid dalam ekstrak secara KLT

Pada analisis kualitatif flavonoid dengan KLT dilakukan untuk menegaskan hasil yang didapat pada skrining fitokimia. Fase gerak yang digunakan pada uji KLT flavonoid adalah butanol : asam asetat : air $(4: 1$ : 5). Sebelumnya fase gerak diekstraksi terlebih dahulu dan diambil lapisan bagian atasnya (Markham,1998). Eluen tidak saling bercampur karena adanya perbedaan kepolaran yang digunakan untuk elusi. Butanol merupakan eluen yang bersifat semi polar, asam asetat dan air merupakan eluen bersifat polar. Berat jenis butanol lebih kecil daripada air sehingga sebagian besar yang berada di fase atas adalah butanol, maka fase gerak yang terambil cenderung bersifat semi polar. Fase gerak yang cenderung semi polar ini dapat mengelusi zat dengan baik karena sifat flavonoid yang semi polar sampai polar.

Berdasarkan profil KLT pada Gambar 1, didapatkan nilai hRf standar quercetin sebesar 96,25 dan hRf flavonoid pada sampel sebesar 87,5. Sebelum diuapi NH3 warna bercak standar quercetin yaitu kuning kecoklatan pada sinar $\mathrm{UV}_{366 \mathrm{~nm}}$ dan setelah diuapi dengan NH3 warna spot dari standar quercetin tidak mengalami perusbahan atau tanpa perubahan. Untuk flavonoid yang terdapat pada sampel warna bercak sebelum diuapi NH3 yaitu kuning redup dan setelah diuapi dengan NH3 tanpa mengalami perubahan.

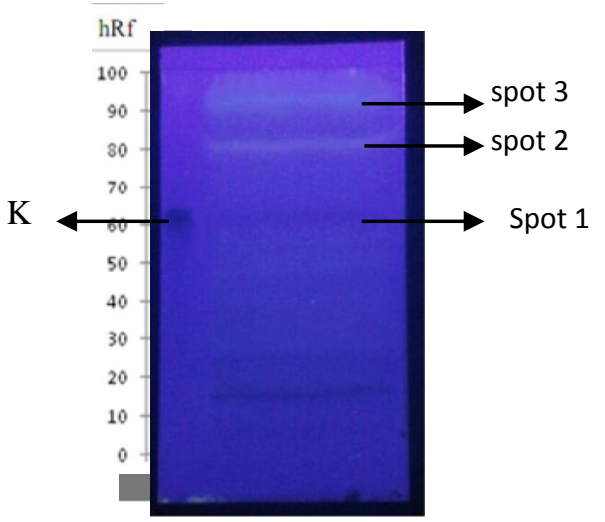

(a)

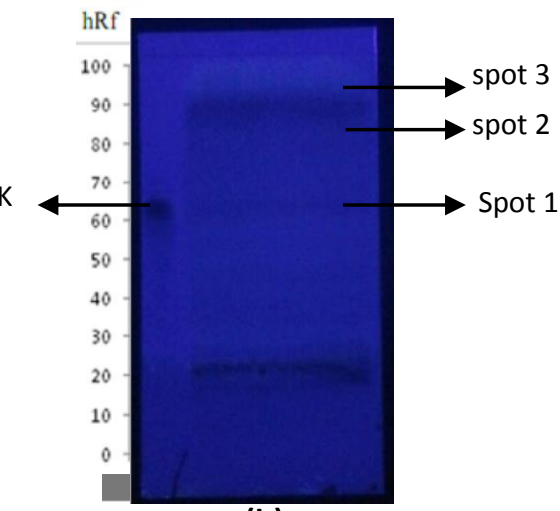

(b)

Gambar 1. Profil KLT ekstrak sarang semut pada UV $366 \mathrm{~nm}$ tanpa amonia (a) dan dengan amonia (b) serta $\mathrm{K}$; kuersetin

Berdasarkan hasil identifikasi secara KLT dan penentuan golongan berdasarkan warna bercak, menunjukkan senyawa kuersetin merupakan golongan Flavonol yang mengandung 3-OH bebas dan mempunyai atau tidak mempunyai 5-OH
Berdasarkan profil KLT dari ekstrak etanol sarang semut menghasilkan warna bercak dan perubahanya setelah disemprot dengan uap ammonia yang dapat dilihat pada table I.

Tabel I. Kemungkinan golongan senyawa berdasarkan warna bercak KLT pada UV 366 sebelum dan sesudah diberi uap NH3

\begin{tabular}{|c|c|c|c|c|c|}
\hline \multirow[b]{2}{*}{ No } & \multirow[b]{2}{*}{ Sampel } & \multirow[b]{2}{*}{ hRf } & \multicolumn{2}{|c|}{ Warna bercak pada UV $366 \mathrm{~nm}$} & \multirow[b]{2}{*}{ *Jenis Flavonoid } \\
\hline & & & $\begin{array}{c}\text { Sebelum } \\
\text { diuapi } \mathrm{NH}_{3}\end{array}$ & Sesudah diuapi $\mathrm{NH}_{3}$ & \\
\hline 1 & $\begin{array}{l}\text { K (Standar } \\
\text { kuersetin) }\end{array}$ & 60 & Kuning redup & $\begin{array}{l}\text { Perubahan warna sedikit } \\
\text { atau tanpa perubahan }\end{array}$ & $\begin{array}{l}\text { Flavonol yang mengandung } 3-\mathrm{OH} \\
\text { bebasdanmempunyai } 5-\mathrm{OH} \text { bebas }\end{array}$ \\
\hline 2 & Spot 1 & 58 & Kuning redup & $\begin{array}{l}\text { Perubahan warna sedikit } \\
\text { atau tanpa perubahan }\end{array}$ & $\begin{array}{l}\text { Flavonol yang mengandung } 3-\mathrm{OH} \\
\text { bebasdanmempunyai } 5-\mathrm{OH} \text { bebas }\end{array}$ \\
\hline 3 & Spot 2 & 78 & Kuning & $\begin{array}{l}\text { Perubahan warna sedikit } \\
\text { atau tanpa perubahan }\end{array}$ & $\begin{array}{c}\text { Flavonol yang mengandung } 3-\mathrm{OH} \text { bebas dan } \\
\text { mempunyai 5-OH bebas }\end{array}$ \\
\hline 4 & Spot 3 & 90 & Hijau-kuning & $\begin{array}{l}\text { Perubahan warna sedikit } \\
\text { atau tanpa perubahan }\end{array}$ & $\begin{array}{l}\text { a. Auron yang tak mengandung 4'-OH bebas } \\
\text { dan flavonontanpa 5-OH bebas } \\
\text { b. Flavonol yang mengandung 3-OH bebas } \\
\text { dan disertai atau tanpa 5-OH bebas }\end{array}$ \\
\hline
\end{tabular}

*Markham, 1988 
Pada tabel I menunjukkan bahwa terdapat 3 spot yang mengindikasikan keberadaan senyawa flavonoid dalam sampel. pada hRf 58 menunjukkan warna bercak dengan sinar UV $366 \mathrm{~nm}$ tanpa NH3 yaitu kuning redup dan setelah diuapi dengan $\mathrm{NH} 3$ perubahan warna sedikit atau tanpa perubahan. Jenis flavonoid yang mungkin padsa spot 1 yaitu flavonol yang mengandung 3-OH bebas dan mempunyai 5OH bebas ( berasal dari dihidroflavonol) (Markham, 1988). Pada spot 2 nilai hRf 78 menunjukkan warna bercak sinar UV $366 \mathrm{~nm}$ tanpa NH3 yaitu kuning setelah diuapi dengan NH3 perubahan warna sedikit atau tanpa perubahan. Jenis flavonoid yang mungkin pada spot 2 dan juga pada spot 3 yaitu flavonol yang mengandung $3-\mathrm{OH}$ bebas dan mempunyai $5-\mathrm{OH}$ bebas (berasal dari dihidroflavonol).

\section{Kadar flavonoid dalam ekstrak sarang semut}

Penetapan kadar flavonoid dalam sampel diawali dengan penetapan panjang gelombang maksimal dan penentuan Operating Time (OT). Penentuan panjang gelombang maksimum dilakukan untuk mengetahui panjang gelombang yang dapat memberikan absorbansi maksimal, sedangkan Operating Time (OT) untuk mengetahui waktu yang stabil saat sampel bereaksi sempurna membentuk kompleks dengan reagen pembentuk warna yang berarti larutan quercetin setelah direaksikan dengan $\mathrm{AlCl} 3$ stabil pada menit tersebut. Panjang gelombang dan OT yang dihasilkan yaitu $429 \mathrm{~nm}$ dan pada menit ke 30 .

Analisis kuantitatif flavonoid total dilakukan dengan pengukuran absorbansi terhadap persamaan regresi larutan standar kuersetin. Warna yang dihasilkan dari larutan standar kuersetin adalah kuning. Semakin tinggi konsentrasi yang digunakan, semakin pekat warna kuning yang dihasilkan.

Berdasarkan kurva kalibrasi pada gambar 2, persamaan regresi linier standar kuersetin adalah sebagai berikut :

$$
\begin{aligned}
& y=0,0585 x+0,0115 \\
& \text { nilai } r=0,9747
\end{aligned}
$$

Nilai $r$ dari persamaan regresi linier tersebut menunjukkan adanya hubungan yang linier antara absorbansi dengan konsentrasi kuersetin. Hal ini ditunjukkan dengan nilai $\mathrm{r}$ yang mendekati 1 yang berarti bahwa persamaan regresi tersebut adalah linier, dimana semakin besar absorbansi menunjukkan semakin besar konsentrasinya.

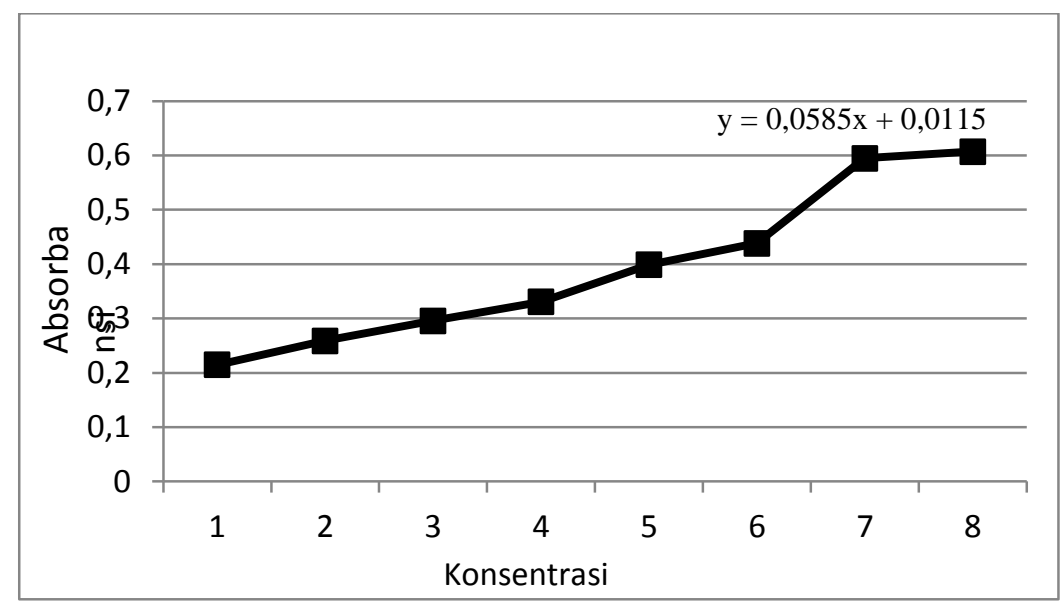

Gambar 2. Kurva Regresi Linier kuercetin pada panjang gelombang $429 \mathrm{~nm}$

Berdasarkan tabel IV, didapatkan nilai $\mathrm{A}=$ $0,0115, \mathrm{~B}=0,0585, \mathrm{r}=0,9747$ dan $\alpha=3,3479$. Dengan demikian persamaan regresi linier yang digunakan dalam perhitungan kadar adalah $\mathbf{Y}=$ $\mathbf{0 , 0 5 8 5 x}+\mathbf{0 , 0 1 1 5}$. Dari rumus regresi linier diperoleh kadar flavonoid total equivalen quercetin pada ekstrak etanol sarang semut sebesar 0,6126 \% b/b.

\section{Simpulan}

Pada ekstrak etanol sarang semut mengandung senyawa flavonoid yang terdiri dari golongan flavonol dengan kadar sebesar 0,6126 \% b b terhadap kuersetin.

\section{Ucapan Terimakasih}

Peneliti mengucapkan terima kasih kepada Yayasan Pendidikan Pharmasi Nasional Surakarta yang telah memberikan Hibah Penelitian Dosen Tahun Anggaran 2014 dan semua pihak yang turut membantu terselesaikannya penelitian ini.

\section{Daftar Pustaka}


Fatmawati, D., Puspitasari, P. K. dan Yusuf I., 2014, Efek Sitotoksik Ekstrak Etanol Sarang Semut (Myrmecodia pendens) Pada Sel Line Kanker Serviks HeLa Uji Eksperimental Secara In Vitro Cytotoxic Effect of Ethanolic Extract of Sarang Semut (Myrmecodia pendens) on HeLa Cervix Cancer Cell Line, Sains Medika, Journal and Medicine and Health, PISSN: 2085-1545 • eISSN: 2339-093X

Frengki, dkk., 2014, Uji Toksisitas Ekstrak Etanol Sarang Semut Lokal Aceh(Mymercodia sp.) dengan Metode BSLT terhadap Larva UdangArtemia salina Leach. Jurnal Medika Veterinaria, ISSN : 0853-1943

Mabry, T.J. K.R. Markham, M.B. Thomas, 1970, The Systematic Identification of Flavonoids, Springer-Verlag, New York

Marianti, Anti, 2012, Aktivitas Antibakteri Fraksi Dari Ekstrak Etanol Umbi Batang Tumbuhan
Sarang Semut (myrmecodia pendens merr.\& 1. M. Perry) Terhadap Escherichia Coli Dan Bacillus Cereus, Students Journals, Vol 1, no. 1.

Markham. K. R., 1988, Cara Mengidentifikasi Flavonoid, Bandung, Penerbit ITB.

Redha, Abdhi, 2010, Flavonoid: Struktur, Sifat Antioksidatif Dan Peranannya Dalam Sistem Biologis, e-Journal Belian Vol. 9 No. 2

Subronto, A. dan H. Saputro. 2006. Gempur Penyakit Sarang Semut. Penerbit Swadaya, Depok.

Suharyanto, Didik Wahyudi, dan Novena YettyL.2012.Metode Ekestraksi Sarang Semut (Myrmecodia pendens) dengan Teknik Maserasi Untuk Menghasilkan Obat Alternatif Kanker Paru. Seminar Nasional Pendidikan Sains 2012. No.ISSN:2089-5828 